\title{
KARAKTERISTIK DAGING IKAN MAS (Cyprinus carpio) YANG DIBERI PAKAN DENGAN KADAR LEMAK YANG BERBEDA
}

\author{
Ningrum Suhenda*' dan Ongko Praseno"
}

\begin{abstract}
ABSTRAK
Percobaan untuk melihat pengaruh pakan dengan kadar lemak berbeda terhadap kualitas daging ikan mas telah dilakukan dengan menggunakan rancangan acak lengkap, empat perlakuan dan tiga ulangan. Perlakuan adalah pakan bentuk pelet yang mengandung lemak sebesar $4 \%, 6 \%$. $8 \%$ dan $10 \%$ dengan kandungan protein sama yaitu $30 \%$ yang diberikan sekenyangnya Penyesuaian jumlah pakan yang diberikan dilakukan tiap dua minggu setelah dilakukan penimbangan ikan. Ikan uji adalah ikan mas dengan bobot rata-rata 27,3 g/ekor yang dipelihara dalam tangki yang terbuat dari serat gelas ukuran $200 \mathrm{~L}$ dengan padat penebaran 15 ekor/wadah Hasil penelitian menunjukkan bahwa pakan dengan kadar lemak berbeda menghasilkan kadar lemak ikan dan retensi lemak yang berbeda nyata $(p<0,05)$. Pakan dengan kadar lemak $8 \%$ memberikan kadar protein ikan sebesar $18,8 \%$ dan kadar lemak terbaik $(7,8 \%)$, serta retensi protein dan retensi lemak masing-masing sebesar $28,6 \%$ dan $56,4 \%$. Kadar asam lemak linolenat (n3) dan linoleat (n6) ikan mas dengan perlakuan kadar lemak $8 \%$ nilainya dua kali lipat daripada perlakuan lainnya. Bagian tubuh ikan mas yang dapat dimakan berkisar antara $27,3 \%-27,9 \%$ dengan mortalitas lebih kecil dari 5\% dan laju sintasannya berkisar antara $95,6 \%-100 \%$ selama pemeliharaan 12 minggu.
\end{abstract}

ABSTRACT: Meat quality of common carp (Cyprinus carpio) fed with diets containing different levels of fat. By: Ningrum Suhenda and Ongko Praseno

An experiment to find the effect of diets containing different levels of fat on meat quality of the common carp was conducted by using a Complete Randomized Design with four dietary treatments and three replicates. Four experimental pellet diets with different fat levels i.e. 4\%, 6\%, 8\%, and $10 \%$. containing the same level of protein (30\%) were used. The fish were fed to satiation and adjustment of the quantity of diets fed to the fish was made every two weeks after fish weighing. The average individual weight of common carp used were $27.33 \mathrm{~g}$. The fish were kept in fiber glass tanks of $200 \mathrm{~L}$ capacity with stocking density of 15 individuals per tank. The result showed that diets containing different levels of fat gave significantly different $(p<0.05)$ fish body fat contents and fat retentions. The diet with $8 \%$ fat gave body protein content $18.76 \%$, the best body fat content $7.78 \%$, and protein and fat retentions were $28.61 \%$ and $56.35 \%$, respectively. Linolenic (w-3) and linoleic $(1,-6)$ acid contents in the fish treated with the diet of $8 \%$ fat were two times higher than other treatments. Percentages of edible portion of fish fed with the different diets ranged from $27.30 \%$ to $27.91 \%$ and the mortality were less than $5 \%$ with the survival rates ranged from $95.55 \%$ to $100 \%$ over the experimental period of 12 weeks.

KEYWORDS: meat quality, common carp, fat level.

\section{PENDAHULUAN}

Dalam menyongsong era globalisasi dan keadaan sosial ekonomi masyarakat yang semakin meningkat maka selain produksi, kualitas daging ikan yang dihasilkan dari kegiatan budi daya perlu mendapat perhatian. Sampai saat ini, pemeliharaan ikan mas terutama dalam keramba jaring apung hanya ditujukan pada peningkatan produksinya dan belum ditujukan pada peningkatan kualitas dagingnya. Untuk memenuhi permintaan konsumen dalam negeri terutama golongan menengah ke atas, kualitas daging ikan yang dihasilkan harus baik, dan dapat ditingkatkan melalui pendekatan penggunaan pakan. Keseimbangan nutrien dalam pakan, tidak saja berpengaruh terhadap pertumbuhan tetapi juga pada kualitas daging. Salah satu faktor yang mempengaruhi kualitas daging ikan antara lain kadar lemak pakan yang komposisinya dikontrol (Halver, 1972).

Kadar lemak daging ikan berpengaruh pada elastisitas atau struktur menbran sel, aroma, tekstur. dan cita rasa. Selanjutnya, pengaruh kadar lemak daging ikan berbanding lurus dengan mutu, rasa, bau (aroma), dan kesukaan konsumen (Lelana et al. 1993). Sedangkan kadar lemak ikan bervariasi menurut kondisi (kualitas) pakan, spesies, umur bagian badan, dan musim bertelur (Suzuki, 1981). Ikan yang diberi pakan dengan kualitas berbeda tidak saja berpengaruh pada kualitas daging tetapi

Peneliti pada Balai Penelitian Perikanan Air Tawar 
juga berpengaruh pada perkembangan sel-sel hati (Ding et al., 1989). Pakan yang banyak mengandung asam lemak tidak jenuh akan mudah teroksidasi menjadi senyawa peroksida yang bersifat racun dan akan menurunkan fungsi normal hati (Hastings, 1976)

Pakan dengan kadar lemak $7 \%$ dan diberikan dengan ransum harian $2 \%$ dan bobot badan dapat meningkatkan kualitas daging ikan lele dumbo (Lelana et al., 1993). Selain sebagai sumber energi, lemak diharapkan dapat disintesis menjadi asam lemak yang termasuk dalam kelompok asam lemak linolenat (Manik \& Djunaidah, 1980). Perkembangan jaringan berlemak pada ikan mas dipengaruhi oleh faktor lemak pakan dan tingginya kandungan energi pakan (Fauconneau et al., 1995).

Tujuan penelitian ini adalah untuk mengetahui pengaruh pakan dengan kadar lemak berbeda terhadap kualitas daging ikan mas

\section{BAHAN DAN METODE}

Penelitian ini dilakukan di Laboratorium Nutrisi Balai Penelitian Perikanan Air Tawar Sukamandi selama 12 minggu. Ikan yang digunakan yaitu ikan mas (Cyprinus carpio) dengan bobot rata-rata 27,3 g/ekor yang diperoleh dari petani ikan di Sukamandi, Subang. Wadah pemeliharaan ikan yang dipergunakan terbuat dari serat gelas berbentuk silinder (diameter $74 \mathrm{~cm}$, tinggi $58 \mathrm{~cm}$ ) dengan volume air $200 \mathrm{~L}$ dan ditempatkan dalam ruang tertutup. Bagian atas setiap wadah percobaan ditutup dengan jaring untuk mencegah ikan meloncat ke luar. Padat penebaran ikan yaitu 15 ekor/wadah

Sebelum digunakan, air ditampung dalam bak penampungan dan diaerasi. Penggantian air sebanyak $80 \%$ dari masing-masing wadah dilakukan pada pagi dan sore hari. Pada waktu penggantian air dilakukan penyifonan kotoran yang ada pada masing-masing wadah

Rancangan percobaan yang digunakan adalah rancangan acak lengkap (RAL) dengan empat perlakuan yaitu pakan dengan kandungan lemak berbeda $(4 \%, 6 \%, 8 \%$, dan $10 \%)$ sedangkan kandungan proteinnya sama (30\%). Setiap perlakuar) diulang tiga kali. Kandungan energi pakan untuk masing-masing pakan yaitu sebesar $2.600,2.700,2.800$, dan 2.900 $\mathrm{Kkal} \mathrm{DE} / \mathrm{kg}$ pakan

Sebelum pakan dibuat, bahan baku pakan yang digunakan dianalisis secara proksimat. Komposisi pakan percobaan (uji) tertera pada Tabel 1. Pakan diberikan dalam bentuk pelet dengan frekuensi pemberian empat kali sehari yaitu pada pukul 08.00 . 11.00, 14.00, dan pukul 17.00. Banyaknya pakan yang diberikan yaitu sekenyangnya (satiation). Penyesuaian jumlah pakan yang diberikan dilakukan tiap dua minggu setelah dilaksanakan penimbangan ikan (sampling)

Penimbangan ikan dalam keadaan basah dilakukan dengan menggunakan timbangan O-Hauss yang mempunyai ketelitian $0,1 \mathrm{~g}$ dengan cara memasukkan ikan ke dalam wadah plastik yang berisi air. Ikan yang mati selama penelitian, ditimbang dan dicatat

Tabel 1. Komposisi (\%) empat pakan percobaan dengan kadar lemak yang berbeda Table 1. Composition (\%) of the four experimental diets with different fat concentrations

\begin{tabular}{lcccc}
\hline \multicolumn{1}{c}{$\begin{array}{c}\text { Bahan makanan } \\
\text { Ingredient }\end{array}$} & \multicolumn{4}{c}{$\begin{array}{c}\text { Kadar lemak (\%) pakan } \\
\text { Fat content (\%) of the feed }\end{array}$} \\
\cline { 2 - 5 } & 4 & 6 & 8 & 10 \\
\hline Tepung ikan (Fish meal) & 21 & 21 & 21 & 21 \\
Bungkil kedelai (Soybean meal) & 28 & 28 & 28 & 28 \\
Dedak halus (Fine rice bran) & 20 & 20 & 20 & 20 \\
Jagung (Corn) & 5 & 5 & 5 & 5 \\
Terigu (Wheat flour) & 10 & 10 & 10 & 10 \\
Vitamin (Vitamin mix) & 2 & 2 & 2 & 2 \\
Mineral (Mineral mix) & 1 & 1 & 1 & 1 \\
Minyak ikan (Fish oil) & 0 & 1 & 2 & 3 \\
Minyak jagung (Corn oil) & 0 & 1 & 2 & 3 \\
Filler (Lignobon) & 13 & 11 & 9 & 7 \\
\hline
\end{tabular}


bobot dan jumlahnya. Pada waktu penghitungan akhir, data tersebut dimasukkan dalam perhitungan produksi dan konversi pakan.

Parameter yang diamati meliputi kadar protein, kadar lemak, retensi protein, retensi lemak, kadar asam lemak dan bagian yang dapat dimanfaatkan (edible portion) yaitu bobot daging ikan. Penentuan kadar protein dengan menggunakan metode Kjeldhal dan kadar lemak dengan metode ekstraksi Soxhlet. Retensi protein dan retensi lemak dihitung menurut Viola \& Rappaport (1979). Analisis kadar asam lemak ikan uji digunakan alat HPLC dan dilaksanakan di Laboratorium Biokimia dan Enzimatik, Balai Penelitian Bioteknologi Tanaman Pangan, Bogor.

Selain itu diamati pula pertumbuhan bobot ratarata individu dan laju sintasan ikan selama penelitian. Respon masing-masing parameter terhadap perlakuan dilakukan dengan menggunakan uji $F$.

\section{HASIL DAN BAHASAN}

\section{Kadar Protein Ikan}

Berdasarkan data pada Tabel 2, perbedaan kadar lemak pakan menghasilkan kadar protein ikan uji pada akhir penelitian tidak berbeda nyata $(p>0,05)$. Kadar lemak pakan sebesar $8 \%$ memberikan kadar protein ikan uji rata-rata tertinggi, yaitu $18,8 \%$.

Kualitas pakan, dalam hal ini kadar lemak pakan berperan dalam menentukan hasil percobaan yang diperoleh. Kualitas daging ikan mas ternyata dapat ditingkatkan melalui pendekatan penggunaan pakan. Lemak dalam pakan mempengaruhi kadar lemak ikan uji dan retensi lemak, serta kadar asam lemak esensial.

Pakan dengan kadar lemak $8 \%$ menghasilkan kadar protein ikan sebesar $18,8 \%$ dan kadar lemak terbaik $(7,8 \%)$. Hal ini sesuai dengan pendapat NRC (1977) bahwa makanan yang diberikan harus dapat diubah menjadi protein tubuh secara efisien.

\section{Kadar Lemak Ikan}

Pada Tabel 2 tercantum bahwa kadar lemak pakan yang berbeda berpengaruh terhadap kadar lemak ikan uji yang berbeda nyata $(p<0,05)$. Kadar lemak pakan sebesar $8 \%$ memberikan pengaruh yang terbaik terhadap kadar lemak rata-rata ikan uji pada akhir penelitian adalah $7,8 \%$

Kadar lemak pakan sebesar $8 \%$ menghasilkan kadar lemak ikan yang terbaik yaitu sebesar $7.8 \%$ dan berbeda nyata $(p<0,05)$ dengan kadar lemak ikan yang diberi pakan dengan kadar lemak $4 \%(8,4 \%)$. Pada umumnya, masyarakat konsumen ikan tidak menyenangi ikan berkadar lemak tinggi. Lelana et al. (1993) menyatakan bahwa kadar lemak daging ikan mempengaruhi mutu, bau (aroma) dan kesukaan konsumen. Selanjutnya, kadar lemak daging ikan berpengaruh pada elastisitas atau struktur membran sel, aroma, tekstur, dan cita rasa. Hasil penelitian Lelana et al. (1993) menunjukkan bahwa kualitas daging ikan lele dumbo lebih baik bila diberi pakan dengan kadar lemak $7 \%$ dan ransum harian $2 \%$.

\section{Retensi Protein}

Hasil analisis statistik retensi protein menunjukkan bahwa kadar lemak pakan yang berbeda memberikan retensi protein yang tidak berbeda (Tabel 3). Retensi protein ikan yang diberi pakan dengan kadar lemak $6 \%$ adalah sebesar $30,8 \%$.

Kadar lemak pakan berbeda tidak berpengaruh nyata terhadap retensi protein pada ikan. Hal ini menunjukkan bahwa pakan dengan kadar lemak berbeda memiliki efektivitas yang sama. Viola \& Rappaport (1979) menggunakan retensi protein sebagai indikator efektivitas pakan.

\section{Retensi Lemak}

Pada Tabel 3 terlihat bahwa kadar lemak pakan yang berbeda berpengaruh nyata $(p<0,05)$ terhadap

Tabel 2. Kadar protein (\%) dan kadar lemak (\%) ikan uji pada akhir penelitian.

Table 2. Protein contents (\%) and fat contents (\%) of the fish body at the end of the experiment.

\begin{tabular}{lrrrr}
\hline \multirow{2}{*}{$\begin{array}{c}\text { Parameter } \\
\text { Parameter }\end{array}$} & \multicolumn{4}{c}{$\begin{array}{c}\text { Kadar lemak (\%) pakan } \\
\text { Fat content (\%) of the diet }\end{array}$} \\
\cline { 2 - 6 } & $\mathbf{4}$ & \multicolumn{1}{c}{$\mathbf{6}$} & $\mathbf{8}$ & \multicolumn{1}{c}{$\mathbf{1 0}$} \\
\hline Kadar protein (Protein contents) & $18.67^{\mathrm{a}}$ & $18.26^{\mathrm{a}}$ & $18.76^{\mathrm{a}}$ & $18.27^{\mathrm{a}}$ \\
Kadar lemak (Fat contents) & $8.37^{\mathrm{b}}$ & $8.97^{\mathrm{c}}$ & $7.78^{\mathrm{d}}$ & $8.05^{\mathrm{d}}$ \\
\hline
\end{tabular}

Angka rata-rata yang diikuti dengan huruf superskrip yang sama tidak berbeda nyata (Mean values followed by the same superscript are not significantly different $)(p>0.05)$ 
Table 3. Retensi protein dan retensi lemak ikan mas selama 12 minggu pemeliharaan.

Table 3. Protein and fat retentions of the fish after 12 weeks of experiment.

\begin{tabular}{ccc}
\hline $\begin{array}{c}\text { Perlakuan/kadar lemak pakan } \\
\text { Treatment/fat content of the feed }\end{array}$ & $\begin{array}{c}\text { Retensi protein } \\
\text { Protein retention }\end{array}$ & $\begin{array}{c}\text { Retensi lemak } \\
\text { Fat retention }\end{array}$ \\
\hline$(\%)$ & $(\%)$ & $(\%)$ \\
\hline 4 & $29.38^{e}$ & $116.07^{\mathrm{a}}$ \\
6 & $30.82^{\mathrm{e}}$ & $96.44^{\mathrm{b}}$ \\
8 & $28.61^{\mathrm{e}}$ & $56.35^{\mathrm{c}}$ \\
10 & $28.64^{\mathrm{e}}$ & $47.67^{\mathrm{d}}$
\end{tabular}

Angka rata-rata yang diikuti dengan huruf superskrip yang sama tidak berbeda nyata (Mean values followed by the same superscript are not significantly different $)(p>0.05)$

retensi lemak ikan uji. Ikan mas yang diberi pakan dengan kadar lemak $4 \%$ retensi lemaknya paling tinggi yaitu sebesar $116,1 \%$. Selanjutnya retensi lemak ikan uji menurun sesuai dengan naiknya kadar lemak pakan berturut-turut $96,4 \%, 56,4 \%$, dan $47,7 \%$

Retensi lemak ikan yang diberi pakan dengan dengan kadar lemak $4 \%$ adalah yang tertinggi $(116,1 \%)$. Nilai ini bukan merupakan retensi murni dari lemak pakan yang diberikan melainkan ada penambahan yang berasal dari karbohidrat (kadarnya paling tinggi) dan protein karena kadar lemaknya terendah (4\%) dibandingkan dengan pakan lain. Jadi dalam hal ini retensi lemak juga diperoleh dari biokonversi karbohidrat dan protein. Retensi lemak ikan yang diberi pakan dengan kadar lemak 8\% adalah sebesar 56,4\%. Hal ini terlihat dari kadar lemak ikan uji yang diberi pakan dengan kadar lemak $8 \%$ pada akhir percobaan nilainya terendah $(7,8 \%)$

\section{Kadar Asam Lemak Ikan Uji}

Hasil analisis asam lemak ikan uji tertera pada Tabel 4. Pada Tabel 4 terlihat bahwa ikan yang diberi pakan dengan kadar lemak $8 \%$ mempunyai kadar asam lemak paling tinggi. Kadar asam lemak linolenat (n3) ikan mas yang diberi pakan dengan kadar lemak $8 \%$ nilainya dua kali lipat dari ikan mas yang diberi pakan dengan kadar lemak 4\%, 6\%, dan 10\% Demikian pula kadar asam lemak linoleat (n6) ikan mas yang diberi pakan dengan kadar lemak $8 \%$ nilainya dua kali lipat dari ikan mas pada perlakuan lainnya.

Kadar asam lemak linolenat (n3 sebesar 0,48\%) dan linoleat ( $n 6$ sebesar $0,4 \%$ ) ikan mas yang diberi pakan dengan kadar lemak $8 \%$ nilainya dua kali lipat dari yang dikandung ikan mas yang diberi pakan dengan kadar lemak 4\% (0,2\% dan 0,2\%), 6\% (0,2\% dan $0,2 \%$ ) dan $10 \%(0,2 \%$ dan 0,2\%). Anonim (1995) menyatakan bahwa asam lemak n3 mempunyai peranan penting dalam kesehatan manusia antara lain mengurangi peluang kematian akibat penyakit jantung dan membantu perkembangan sel otak bayi. Selanjutnya Muchtadi \& Elisabeth (1995) menyatakan bahwa hubungan asam lema n3 dalam pencegahan beberapa penyakit degeneratif telah diketahui. Beberapa penelitian menunjukkan bahwa n3 terdapat dalam jumlah yang cukup tinggi dalam jaringan otak dan retina manusia. Selain sebagai sumber energi, lemak diharapkan dapat menyediakan asam lemak yang termasuk dalam kelompok asam lemak linolenat (Manik \& Djunaidah, 1980).

Tabel 4. Kadar asam lemak (\%) ikan mas yang diberi pakan dengan kadar lemak berbeda

Table 4. Body fatty acid contents (\%) of the common carp fed with diets of different fat levels

\begin{tabular}{cccccccc}
\hline $\begin{array}{c}\text { Kadar lemak (\%) pakan } \\
\text { Fat contents of diets (\%) }\end{array}$ & $\begin{array}{c}\text { Miristat } \\
\text { Myristic }\end{array}$ & $\begin{array}{c}\text { Palmitat } \\
\text { Palmitic }\end{array}$ & $\begin{array}{c}\text { Palmitoleat } \\
\text { Palmitoleic }\end{array}$ & $\begin{array}{c}\text { Stearat } \\
\text { Stearic }\end{array}$ & $\begin{array}{c}\text { Oleat } \\
\text { Oleic }\end{array}$ & $\begin{array}{c}\text { Linoleat Linoleic Linolenat } \\
\text { Linolenic }\end{array}$ \\
\hline 4 & 0.12 & 0.11 & 0.24 & 0.12 & 0.04 & 0.23 & 0.22 \\
6 & 0.13 & 0.10 & 0.23 & 0.11 & 0.04 & 0.21 & 0.22 \\
8 & 0.31 & 0.18 & 0.38 & 0.23 & 0.05 & 0.41 & 0.48 \\
10 & 0.20 & 0.09 & 0.28 & 0.12 & 0.04 & 0.21 & 0.20 \\
\hline
\end{tabular}


Hasil penelitian tentang jenis ikan yang memiliki kandungan $\mathrm{n} 3$ masih langka untuk ikan budi daya air tawar. Tersedianya data atau informasi tentang kandungan n3 yang bermanfaat bagi kesehatan manusia akan meningkatkan konsumsi ikan bagi masyarakat Indonesia

Kandungan asam lemak nonesensial lainnya seperti miristat, palmitat, palmitoleat, stearat, dan oleat ikan yang diberi pakan dengan kadar lemak $8 \%$ jauh lebih tinggi dibandingkan dengan yang dikandung ikan yang diberi pakan dengan kadar lemak 4\%,6\%, dan 10\% (lihat Tabel 5).

\section{KESIMPULAN}

Dari hasil penelitian yang dilakukan dapat diambil kesimpulan bahwa pakan dengan kadar lemak $8 \%$ menghasilkan kadar protein ikan mas sebesar $18,76 \%$ dan kadar lemak terbaik $7,78 \%$, retensi protein $28,61 \%$ dan retensi lemak $56,35 \%$. Kadar asam lemak linolenat $(n-3)$ dan linoleat $(n-6)$, yang dikandung ikan mas yang diberi pakan dengan kadar lemak $8 \%$ dua kali lipat yang dikandung ikan yang diberi pakan dengan kadar lemak 4\%,6\%, dan 10\%. Bagian yang dapat dimanfaatkan/dimakan dan

Tabel 5. Edible portion dan pertumbuhan bobot rata-rata individu ikan mas yang diberi pakan dengan kadar lemak berbeda.

Table 5. Edible portion and growth in average individual weight of common carp fed with diets of different fat contents.

\begin{tabular}{lcccc}
\hline \multicolumn{1}{c}{$\begin{array}{l}\text { Parameter } \\
\text { Parameter }\end{array}$} & \multicolumn{4}{c}{$\begin{array}{c}\text { Kadar lemak (\%) pakan } \\
\text { Fat content (\%) of the diet }\end{array}$} \\
\cline { 2 - 5 } & $\mathbf{4}$ & 6 & $\mathbf{8}$ & 10 \\
\hline & 27.91 & 27.91 & 27.32 & 27.3 \\
$\begin{array}{l}\text { Bagian yang dapat dimanfaatkan (\%) } \\
\text { Edible portion (\%) }\end{array}$ & & & & $34.45^{\mathrm{a}}$ \\
$\begin{array}{l}\text { Pertumbuhan bobot rata-rata individu (g) } \\
\text { Growth in individual weigth }(g)\end{array}$ & $37.57^{\mathrm{a}}$ & $36.80^{\mathrm{a}}$ & $35.52^{\mathrm{a}}$ & 34 \\
\end{tabular}

Angka rata-rata yang diikuti dengan huruf superskrip yang sama tidak berbeda nyata (Mean values followed by the same superscript are not significantly different) $(p>0.05)$

\section{Bagian yang Dapat Dimanfaatkan}

Bagian daging ikan mas yang dapat dimanfaatkan/ dimakan (edible portion) dari ikan yang diberi pakan dengan kadar lemak berbeda tertera pada Tabel 5 . Pada tabel ini terlihat bahwa bagian yang dapat dimanfaatkan ikan mas setelah 12 minggu dipelihara dan diberi pakan dengan kadar lemak berbeda ternyata sama (berkisar antara 27,3\%-27,9\%). Pertumbuhan ikan yang baik tidak saja dilihat dari produksinya tetapi harus dilihat pula dari kualitas dagingnya karena sebagian besar dari tubuh ikan yang dikonsumsi adalah dagingnya.

\section{Pertumbuhan Bobot Rata-rata Individu}

Berdasarkan hasil analisis ragam ternyata bahwa ikan mas yang diberi pakan dengan kadar lemak berbeda pertumbuhan bobot rata-rata individunya tidak berbeda nyata $(p>0,05)$ seperti yang dapat dilihat pada Tabel 5

Mortalitas ikan uji selama pemeliharaan 12 minggu cukup baik yaitu di bawah 5\% dengan laju sintasan berkisar antara 95,6\%-100\% pertumbuhan bobot rata-rata individu ikan mas sama untuk semua perlakuan.

\section{DAFTAR PUSTAKA}

Anonim. 1995. Potensi sumber daya perikanan sebagai penghasil omega-3. Makalah Seminar Teknologi Pemanfaatan Minyak Ikan sebagai Sumber Omega3 untuk Kebutuhan Nutrisi dan Kesehatan. Jakarta. 22 Maret 1995 Puslitbangkan, Dept. Pertanian

Ding, L.M., Yongqing, and Xianghua, L. 1989. Improvement of meat quality of grass carp, Ctenopharyngodon idellus (CUV, et val.). In: S. S. de Silva (Ed). Fish nutrition research in Asia, Proceeding of the third Asian Fish Nutrition Network Meeting. Asian Fish. Soc. Spec. Publ 4, AFS, Manila, Philippines. p. 148-152

Fauconneau, B., Durante, H.A., Laroche, M., Marcel, J. and Vallot, D. 1995. Growth and meat quality relations in carp. Aquaculture 129: 265-297

Halver, J.E. 1972. Fish Nutrition. Acad. Press Inc., New York, $713 \mathrm{p}$.

Hastings, W.H. 1976. Fish Nutrition and Fish Feed Manufacture. Rep. From FAO, FIR: AQ/Conf/76/R. 23 Rome, Italy. 13 pp. 
Lelana, I.Y.B., Soebiantoro, B., Sukardi, and Ustadi 1993. Komposisi pakan dan cara pemberiannya untuk memperbaiki tekstur daging lele dumbo (Clarias gariepinus). Laporan Penelitian, Lembaga Penelitian UGM. $25 \mathrm{pp}$

Manik, R. dan Djunaidah, I.S. 1980. Makanan buatan untuk larva udang Penaeid. Dalam: Pedoman Budidaya Udang Penaeid. Direktorat Jenderal Perikanan, Dept. Pertanian. p. 83-94.

Muchtadi, D. and Elisabeth, J. 1995. Formulasi asam lemak omega-3 dalam produk pangan. Makalah Seminar Teknologi Pemanfaatan Minyak Ikan sebagai
Sumber Omega-3 untuk Kebutuhan Nutrisi dan Kesehatan. Jakarta 22 Maret 1995. Puslitbangkan. Dept. Pertanian.

NRC. 1977. Nutrients Requirements of Warmwater Fishes. National Academy of Sciences, Washington D.C. $78 \mathrm{pp}$.

Suzuki, T. 1981. Fish and Krill Protein: Processing Technology. Applied science publishers Ltd., London.

Viola, S. and Rappaport, U. 1979. The "Extra Calorie Effect" of Oil on Nutrition of Carp. Bamidgeh. 31(3): 51 69. 